\title{
Customer Based Retail Brand Equity (RBE) Dimensions Effect on Retail Brand Equity for OK Supermarket in Bindura
}

\author{
Albert Musekiwa ${ }^{1}$, Douglas Chiguvi $^{1} \&$ Hope Hogo ${ }^{1}$ \\ ${ }^{1}$ Bindura University, P. Bag 1020, Bindura, Zimbabwe \\ Correspondence: Albert Musekiwa, Bindura University, P. Bag 1020, Bindura, Zimbabwe. E-mail: \\ musekiwalbert@gmail.com
}

Received: June 13, 2013

Accepted: August 20, $2013 \quad$ Online Published: September 18, 2013

doi:10.5539/ijbm.v8n19p45

URL: http://dx.doi.org/10.5539/ijbm.v8n19p45

\begin{abstract}
The concept of retail brand equity has become a competitive tool for successful retailers in today's competitive market characterised by increase in demands by customers, increased competition and shrinking disposable income. Most stores have realised that it is cheaper to retain than to attain new customers through brand equity. This study sought to determine the nature of relationship between retail brand equity dimensions and retail brand equity for OK supermarket in Bindura. OK supermarkets are the biggest retail chain in Zimbabwe by number of outlets and market share but with dollarization the country has seen increased interest by big some of the big players in Southern Africa like Pick n Pay and Shoprite. It follows that for OK to maintain its pole position it can no longer afford to do business as usual, brand equity provides a sustainable competitive advantage. A sample of 100 respondents was interviewed at the store front. The results revealed that brand awareness, loyalty and perceived quality have significant impact on brand equity. The store managers were urged to increase promotional activities, loyalty programs and psychological factors (tangibles and intangibles) so that the firm could increase brand equity.
\end{abstract}

Keywords: retail brand equity (RBE), retail awareness, retail association, perceived quality, retail loyalty

\section{Introduction}

The concept of retailer brand equity has attracted the attention of marketing practitioners and researchers over the recent years (Arnett et al, 2003; Krammer, 1999; Thompson, 1998). Successful retailers depend on combining the success of the manufacturer's brand and the service nature of the industry. The different dimensions of in store setting such as colour, smell, music, crowding can influence consumer's perceptions of store ambience. These help customers to decide whether or not they visit the store, how greatly they spend time in it, and how much money they spend in it (Grewal et al, 2003).Baker et al (2002) postulate that store environmental factors significantly affect consumer's perceptions of merchandise (price and quality) and employee service. The increase in consumer demands, competition and slow market growth are some of the factors that have complicated the marketing environment (Bloemer \& Oderken-Schrodder, 2002). Consequently, retail brand equity has become a strategic issue in the business performance. Retailer equity provides benefits like the retailer can charge premium price, guaranteed repeat purchases, it provides competitive advantage where competing products provide same benefits, and the retailer can successfully develop private labels which over the years have contributed a large proportion to sales with some cases of $70 \%$ of sales (Carpenter and Tybout, 1998).

\subsection{Background: OK Supermarkets in Zimbabwe}

OK supermarkets have been operating in Zimbabwe since 1942 providing a range of retail products and allied services in response to customer demands. It trades under four brand names: OK stores, Bon Marche', OK express and OK Mart (okziminvestor, 2012). It covers three main product categories namely: grocery, basic clothing and textiles and houseware. The groceries category includes dry groceries, butchery, delicatessen, takeaway, bakery, provisions, fruit and vegetables. The bakery and fruit and vegetables are outsourced to Innscor and Favco respectively (okziminvestor, 2013).The store targets low, middle and high income customers. It adapts its offerings to suit the different customers segments. For example the product range you would find in Bon Mache Borrowdale is targeted to the high income while that you would find in OK Mbare is targeted to low income customers. 
OK supermarkets has 52 branches nationwide making it have the second biggest network of branches after Spar with 100 including its franchisees(okziminvetsor,2013; spar, 2013). Research has shown OK as the most preferred outlet, followed by Spar with 24\% while TM has 15\% market share. In terms of food and groceries OK with $71 \%$ market share had most often used outlets, followed by TM with 59\% while Spar had 56\%. The market dominance of OK supermarkets nationally is also found in OK supermarket Bindura where this study will be focused. The success of OK supermarkets since dollarization of the Zimbabwean economy has largely been due to its ability to reshape the supermarket experience (Reyes, 2005). It has brought so much retail innovation and shoppertainment in the country. The economic stability that Zimbabwe has enjoyed since 2009 has made the country an attractive destination for new players in the retail industry. The country has seen Pick n Pay one of Southern Africa's big players in retail industry investing \$13million for $49 \%$ stake in TM supermarkets. Shoprite another big player in the region already has a footprint in the country through a branch in Bulawayo. Spar continues to grow with its franchise approach. The retail industry has become so attractive due to high returns that have seen supermarkets that were small family businesses a couple of years ago such as Food World, Afro Foods and Shoppa Stoppa now having a network of 16 branches nationwide and having monthly revenue of \$2million a month(ZIA,2013). Consequently, OK supermarket cannot continue to do business as usual, brand equity becomes a pillar for its continued success. A number of researches have been made on customer based brand equity in other countries but in Zimbabwe a few have been done such as Evans et al (2011) based on condoms and Mutsikiwa et al (2013) based on advertising influence on brand equity and there is none on supermarket industry. The study will make contribution towards retail brand equity theories and literature from a developing country perspective. Furthermore customer based brand equity provides competitive edge for market leaders in any industry hence it becomes imperative that grocery managers understand the concept.

\subsection{Research Problem}

The growth of competitor supermarkets as well as the coming in of new and experienced supermarket chains in the country has a lot of implications for OK supermarkets which has been a market leader in the industry for quite sometime. New and stronger competitors will eat into the market share of OK supermarket and there is likely to be fierce competition for the customer's dollar that will give rise to increased operating costs and eventually reduced profits. Consequently the future in retailing belongs to those that are able to retain and maximise revenue from the customer through retail brand equity which becomes a sustainable competitive advantage for future market leaders.

\subsection{Purpose of the Study}

The study sought to determine the nature of relationship between retail brand equity dimensions and retail brand equity amongst $\mathrm{OK}$ supermarket customers.

\subsection{Review of Literature}

Brand equity as a concept began was popularised in the 1980's by advertising practitioners (Chieng and Goi, 2011).Early researches on this area were based on financial techniques but recently they have become customer based. According to Keller(1998) brand equity is the power of the brand that is built in the minds of the consumers on the basis of what they have learnt, seen, felt and heard about the brand. Brand equity is a critical factor in company profitability. Strong brand equity enables organisations to command premium price, capture and maintain market share, sustain longer product life spans, support new product line extensions, attract investors and ward off competition (Keller, 1993). The advertising agency Young and Rubicam has provided the brand asset valuator (BAV) model which considers that brand equity has five key components: differentiation, energy, relevance, esteem and knowledge. Keller (1993)'s brand resonance model requires that six brand building blocks be established with customers. It requires that brand: salience, performance, imagery, judgments, feelings and resonance is provided in order to create significant brand equity. Many studies have used Aaker(1991) brand equity model which has four dimensions of brand equity namely brand loyalty, brand awareness, perceived quality and brand association (Aaker, 1991; Yoo et al 2000; Washburn and Plank 2002; Kim and Kim 2004; Pappu at al 2005; Atilgan et al 2005).In this study the four brand equity dimensions will be adapted to suite the uniqueness of retail setting to become retailer loyalty, retailer awareness, retailer, retailer perceived quality and retailer association. Retailer loyalty is one retailer equity dimension which researchers such as Dick and Basu (1994) have argued should be measured both behaviourally and attitudinally. Loyalty is a strong commitment to rebuy or repatronise a particular product regardless of situation (Oliver, 1999).According to Aaker (1991) it is an attachment that a customer has to a brand. It reflects how likely a customer is to switch to another brand when for example there is a change in price and features. Awareness is found in all brand equity models (Kapferer, 1997). It is the ability to identify the brand under different conditions linking the brand name, logo; symbol etc to certain 
associations in memory (Keller, 2003).A recognised brand is more likely to be selected over unknown brand. Retailer perceived quality is an intangible overall feeling about a brand that affects market share, price and profitability (Aaker, 1991). According to Zeithaml (1988) it is consumer's judgment about a retailer's overall excellence or superiority. It influences directly buying decisions and brand loyalty when there is no motivation for detailed analysis. Customers tend to choose brand based on perceived quality not on detailed specifications. The retail items that would determine perceived quality include store design and visual merchandising, customer service and pricing. Retailer associations are informational nodes linked to a brand node providing meaningful information about the brand for consumers (Keller, 2003; Krishnan, 1996). Ultimately, the success of a brand and a retailer depends on how closely the images of the selling organisation and the brands meet the expectations of the consumer (Porter and Claycomb, 1997).

\section{Conceptual Framework and Hypothesis}

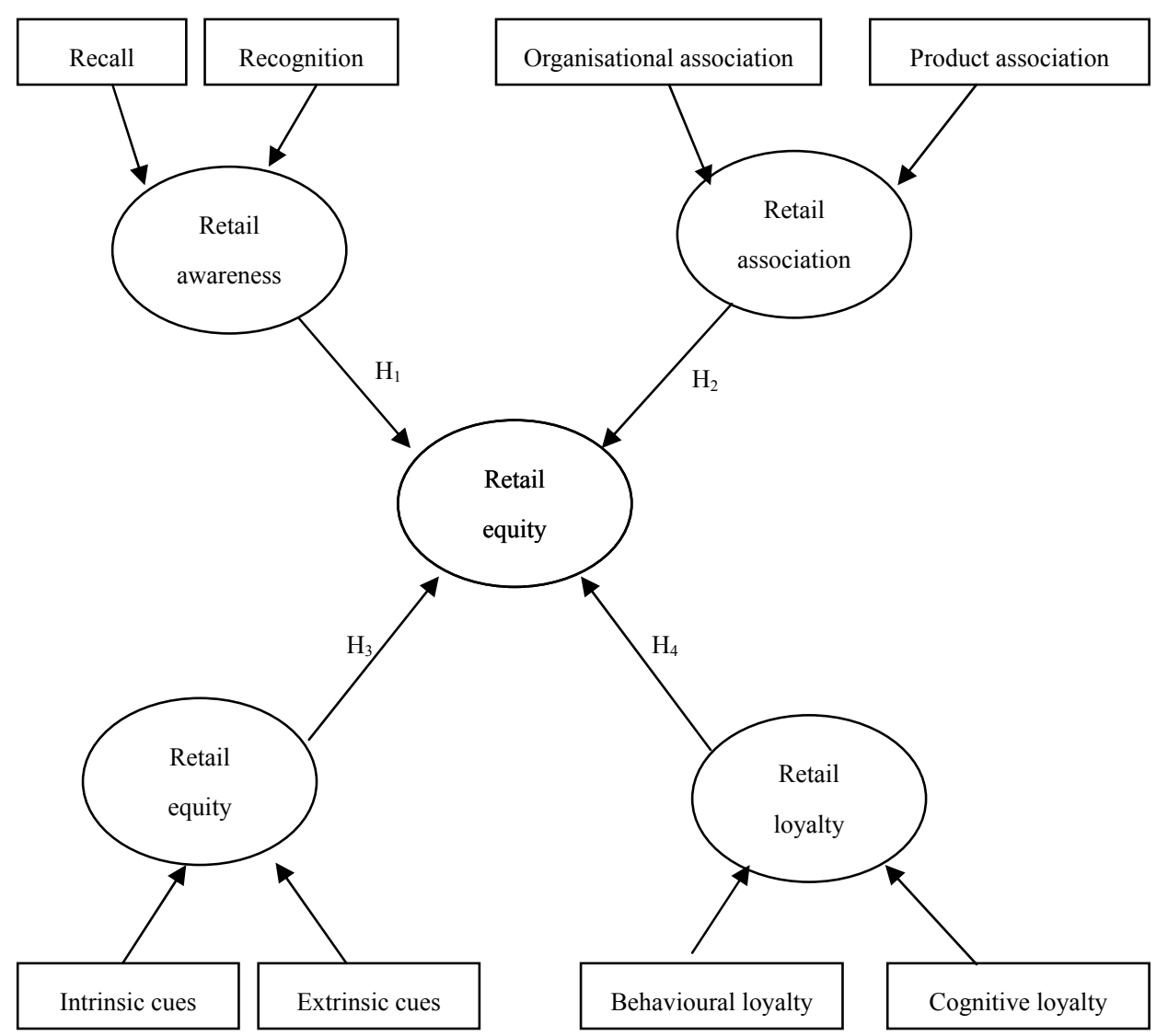

Figure 1. Conceptual framework for measuring customer based retail equity

Source: Adapted from Chieng and Goi (2011).

\subsection{Hypothesis}

The study sought to determine the nature of relationship between retail equity dimensions and retail equity. The following hypotheses have been developed to test the significance of the relationships.

\subsubsection{Brand Awareness and Equity}

Brand awareness can be divided into brand recognition and brand recall. Consumers reach purchase decision making by using heuristics such as "buy brands they have heard of" or "choose the brand they know" (Keller, 1993). Atilgan et al (2005) argues that brand equity occurs when consumers are aware and familiar with the brand at high level and hold some strong favourable, unique brand association in memory. Brand recognition is important for new brands while brand recall is important for well known brands (Aaker, 1996). Studies have 
confirmed that retail awareness has a significant positive effect on retail equity(Yoo et al, 2000; 2006). Consequently, with these assertions the following hypothesises have been developed:

$\mathrm{H}_{1}$ : Retail awareness has a positive impact on retail equity.

\subsubsection{Retail Association and Equity}

Retail association is the core asset for building strong brand equity (Chen, 2001).It can be divided into product associations and organisational. Product associations can include price, quality and usage. Organisational associations would include corporate ability and corporate social responsibility. Researchers have concluded that retail association has a significant positive effect on retail equity (Yoo et al, 2000; 2006).This has led the study into the following hypothesis

$\mathrm{H}_{2}$ : Retail association has a positive impact on retail equity.

\subsubsection{Perceived Quality and Equity}

Perceived quality has been considered as the primary dimension in customer based retail brand equity (Aaker,1996). Jones et al (2002) posit that there is direct relationship between perceived quality and repurchase intention, recommendation and resistance to better alternatives which are at the core of retail brand equity. Product cues can be divided into intrinsic and extrinsic nature (Steenkamp, 1997; Zeithaml 1988). Intrinsic attributes cannot be changed or experimentally manipulated without changing physical nature of the product for example colour and flavour. Extrinsic attributes are external to the product such as price and store. Consumers tend to depend on extrinsic cues when they have inadequate information about the product (Zeithaml, 1988). Intrinsic cues have higher predictive value and are better influencers in judging quality than extrinsic cues (Fiore and Damhorst, 1992). Olsen et al (2011) have concluded that intrinsic cues are mainly responsible for developing consumer's perception about quality variation while extrinsic cues have minor role. Extant literature shows that perceived quality is directly related to brand equity(Umar et al, 2012; Nguyen, 2012; Nguyen et al, 2011; Loureiro and Francisco, 2011; Erenkol and Duygun, 2010). Therefore in this study the author suggest the following hypothesis.

$\mathrm{H}_{3}$ : Perceived quality has a positive impact on retail equity.

\subsubsection{Retail Loyalty and Equity}

Aaker(1991) postulates that retail equity is a marketing pattern with the purpose of promising loyalty by enhancing consciences, brand association and other equities. Most researches claim equity can influence consumer loyalty in a direct way while Gustafsson and Johnson (2002) put that brand equity influence loyalty indirectly as it depends on consumer's experience with the brand and brand experience is the only way for gaining consumer loyalty. Chaudhuri and Holbrook (2001) posit that there are two major values in equity: hedonistic and utility value. The study concludes that there is a positive linear connection in hedonistic values between brand equity and loyalty while there is a negative linear connection in utility values between equity and loyalty. Retailer loyalty can be looked at from two perspectives namely cognitive loyalty and behavioural loyalty (Keller, 1998). Behavioural loyalty is linked to consumer behaviour in the marketplace as shown by repeated purchases. Cognitive loyalty means a brand is the first one to appear in the consumer's mind when the need to make purchase decision arises. Keller (1998) further states that one of the characteristics of brands with strong brand equity is strong brand loyalty. Aaker (1991) also supports this by his assertion that brand loyalty could be considered both a dimension and an outcome of brand equity. This leads this study into the following hypothesis:

$\mathrm{H}_{4}$ : Retail loyalty has a positive impact on retail equity.

\section{Measurement}

Responses to the dimensions were elicited using 5 point likert scales which were 5-strongly agree, 4-agree 3-not sure, 2-disagree, 1-strongly disagree. The responses were obtained for retail brand equity and its four dimensions: awareness, association, loyalty and perceived quality. The questionnaire was initially given to one university marketing lecturer so that he could improve on content validity. He suggested some improvements which were taken into account. It was then pretested at OK Rezende in Harare CBD. There were some ambiguous questions that the researcher rephrased so as to come with the final questionnaire (see Table1).

The scales were evaluated for validity and reliability. Pearson's correlations were calculated between brand equity and its dimensions. Reliability was measured using cronbach alpha (see Table 2). Cronbach alpha ranging from 0.73 to 0.92 and retail brand equity had overall cronbach alpha of 0.82 . This shows a coefficient exceeding the cut of value of 0.7 recommended by Nunnally (1978) hence the reliability was high. Validity is shown in Table 3 where correlations ranged from 0.78 to 0.89 which is a high positive correlation between brand equity and its 
dimensions hence the scales were valid. Factor analysis was used in analysis of the store awareness, store associations, perceived quality, store loyalty and brand equity. Store awareness was obtained from data reduction of questions 1 to 11 , store associations questions 12 to 16 , perceived quality 17 to 29 , store loyalty 30 to 34 and the data for store awareness, store association, perceived quality and store loyalty were used in obtaining brand equity.

Table 1. Questionnaire on store brand equity and its dimensions

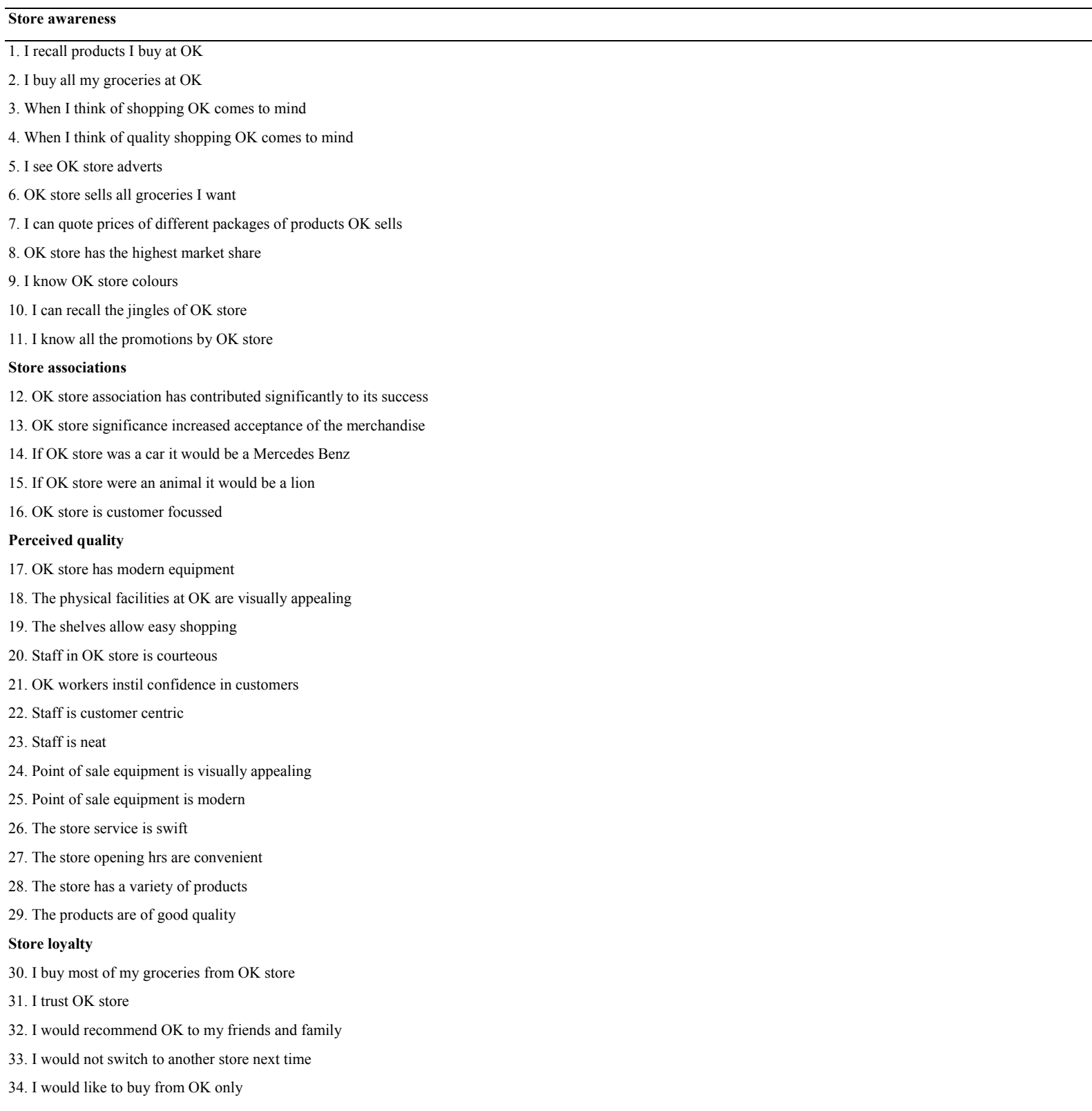

Table 2. Reliability

\begin{tabular}{lll}
\hline RBE dimension & No of items & Cronbach alpha \\
\hline Store awareness & 11 & 0.772 \\
Store associations & 5 & 0.73 \\
Perceived quality & 13 & 0.916 \\
Store loyalty & 5 & 0.791 \\
Retail brand equity & 4 & 0.824 \\
\hline
\end{tabular}


Table 3. Validity (Pearson's correlation)

\begin{tabular}{lllll}
\hline & Store awareness & Store association & Perceived quality & Store loyalty \\
\hline Retail brand equity & 0.79 & 0.894 & 0.794 & 0.782 \\
\hline
\end{tabular}

\subsection{Correlations Results}

The correlations of the retail equity dimensions revealed that store awareness and store association had a strong positive correlation of 0.8 (Table 4). For the other dimensions the correlations were weak ranging from 0.425 to 0.6. According to Salkind (2008) the best predictor variables are those that do not correlate with each other but correlate with what is being predicted. Store awareness and store association were closely related hence one of them was dropped so the conceptual framework changed to Figure 2.

Table 4. Correlations of retail brand equity dimensions

\begin{tabular}{lllll}
\hline RBE dimension & Store awareness & Store association & Perceived quality & Store loyalty \\
\hline Store awareness & 1 & 0.753 & 0.49 & 0.425 \\
Store association & 0.753 & 1 & 0.60 & 0.596 \\
Perceived quality & 0.49 & 0.60 & 1 & 0.458 \\
Store loyalty & 0.425 & 0.596 & 0.458 & 1 \\
\hline
\end{tabular}

\section{Results}

The study has given final linear multiple regression for calculating brand equity as $Y=0.396 X_{1}+0.299 X_{2}+0.306$ $X_{3}-0.05$, where $\mathrm{Y}$-retail brand equity, $\mathrm{X}_{1}$-awareness, $\mathrm{X}_{2}$-perceived quality, $\mathrm{X}_{3}$-loyalty. The equation shows that brand equity depends on awareness, perceived quality and loyalty. An increase in at least one of the dimensions will have a direct proportionate increase in brand equity.

\subsection{Awareness and RBE}

$\mathrm{H}_{1}$ was that retail awareness has a positive impact on retail equity. Regression analysis (Table 5) showed confirms that awareness has a significant impact on retail equity. Awareness has a beta value of 0.416 showing strength of relationship of approximately $42 \%$. This implies for every unit increase in awareness there is $42 \%$ increase in brand equity provided other variables are held constant.

\subsection{Perceived Quality and RBE}

$\mathrm{H}_{3}$ puts that perceived quality has a positive impact on retail equity. This hypothesis has been supported by the regression analysis (Table 5). It has a beta value of 0.397 which shows strength in relationship of $40 \%$. For every unit increase in perceived quality there is $40 \%$ increase in brand equity provided other variables are constant.

\subsection{Loyalty and RBE}

$\mathrm{H}_{4}$ was that retail loyalty has a positive impact on retail equity. The regression analysis has confirmed that loyalty has a significant impact on retail equity. Loyalty has a beta value of 0.423 which shows strength in relationship of $42 \%$. This means for every unit increase in loyalty there is $42 \%$ increase in brand loyalty when other variables are constant.

Customers' retail brand equity is significantly influenced by loyalty, awareness and perceived quality. The three dimensions are equally important to customers. 
Table 5. Regression analysis of brand awareness, perceived quality, loyalty and brand equity

\begin{tabular}{|c|c|c|c|c|c|c|c|}
\hline \multicolumn{8}{|c|}{ Coefficients $^{\mathrm{a}}$} \\
\hline & & \multirow{2}{*}{\multicolumn{3}{|c|}{ Unstandardized Coefficients }} & \multirow{3}{*}{$\begin{array}{c}\begin{array}{r}\text { Standardized } \\
\text { Coefficients }\end{array} \\
\text { Beta }\end{array}$} & \multirow[b]{3}{*}{$\mathrm{T}$} & \multirow[b]{3}{*}{ Sig. } \\
\hline & & & & & & & \\
\hline \multicolumn{2}{|l|}{ Model } & B & & Std. Error & & & \\
\hline \multirow[t]{4}{*}{1} & (Constant) & & -.050 & .076 & & -.656 & .514 \\
\hline & Storeawarene & & .396 & .024 & .416 & 16.337 & .000 \\
\hline & Percquality & & .299 & .020 & .397 & 15.319 & .000 \\
\hline & Storeloyalty & & .306 & .018 & .423 & 16.931 & .000 \\
\hline a. Depe & lent Variable: $b$ & & & & & & \\
\hline
\end{tabular}

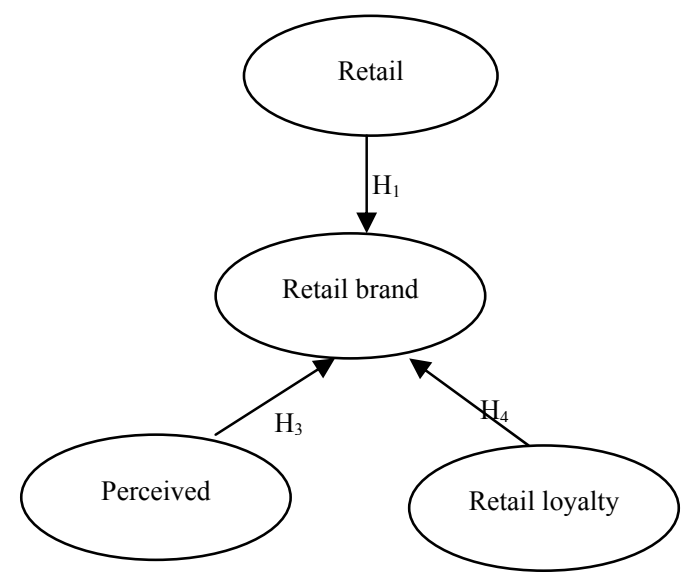

Figure 2. Revised conceptual framework for measuring customer based retail equity

\section{Discussion}

The study has supported $\mathrm{H}_{1}$ which posit that retail awareness has a positive impact on retail equity thus confirming Yoo et al $(2000 ; 2006)$. This finding shows that retail awareness is important in having retail equity. As a result the firm should increase promotional activities like advertising, sales promotions, direct sales, public relations and publicity activities. Once customers' awareness about the store is increased this translate into increased retail brand equity.

There is also a positive correlation between perceived quality and brand equity thereby confirming $\mathrm{H}_{3}$ that says perceived quality has a positive impact on retail equity. Relatively perceived quality has the minimum effect on brand equity although it's almost equal to that of loyalty. The finding supports the findings (Umar et al, 2012; Nguyen, 2012; Nguyen et al, 2011; Loureiro \& Francisco, 2011; Erenkol \& Duygun, 2010) that perceived quality has a positive relationship to brand equity. The firm can increase brand equity through increasing perceived quality variables. These include psychological factors that are either tangible or intangible. Tangibles include displays, fixtures, signage, angles, sightlines, staff proficiency and customer service. Intangibles include those things that affect customer senses such as light, colour, texture, shape and atmospherics.

Loyalty has a positive beta value that is similar to that of awareness which shows the two variables have similar effect on brand equity. The result also supports $\mathrm{H}_{4}$ that says retail loyalty has a positive impact on retail equity. This confirms studies by Chaudhuri and Holbrook (2001) \& Keller (1998) which concluded that RBE and loyalty are positively related while disconfirming Gustafsson and Johnson (2002)'s assertion that RBE and loyalty are indirectly related. The firm should increase loyalty programmes which build trust and word of mouth. Once customers have developed trust they can become loyal and can recommend the firm to others.

The study sought to determine the nature of relationship between brand equity dimensions and brand equity. The results of the study was shows that there is a positive relationship between brand equity and its dimensions as 
shown from the linear multiple regression $Y=0.396 X_{1}+0.299 X_{2}+0.306 X_{3}-0.05$. The regression shows that an increase in any one of the dimensions will be followed with an increase in brand equity. However, it is important to note that the best results of increase in brand equity require an increase in all the dimensions. Under conditions of limited resources a firm can focus on any one dimension which will resultantly lead to an increase in brand equity.

The study has implications for managers which include that awareness and loyalty are the most effective way of increasing brand equity and the two are closely followed by perceived quality. It is important to note that an increase in any one dimension can only lead to increase in brand equity if the other dimensions are not changed otherwise if the other dimensions are reduced more than the increase of the other dimension there will be net reduction in brand equity. However the best increase in brand equity is through increasing each of the dimensions.

\section{Conclusion}

The study has shown that an increase in at least one of the dimensions will lead to proportional increase in brand equity. Awareness and loyalty have the greatest effect on brand equity while perceived quality closely follows. It can be observed that each of the brand equity dimensions has impact on brand equity. The most ideal situation would be to increase all the dimensions so that maximum brand equity can be obtained. On the contrary a decrease in any one of the dimensions would lead to decrease in brand equity if the other dimensions are held constant. The study has shown that awareness and association have a similar impact on brand equity hence it gives brand equity conceptual framework that has three (as shown in Figure 2) instead of four dimensions. Indeed the study has opened interest for further research on the brand equity on OK supermarkets chain not just one, brand equity based on demographic factors such as gender, income and age. It would be interesting to note the effect of the brand equity factors based on these different demographic factors.

\section{References}

Aaker, D. A. (1991). Managing Brand Equity. New York: The Free Press.

Aaker, D. A. (1996). Building Strong Brands. New York: The Free Press.

Arnett, D. B., Laverie, D. A., \& Meiers, A. (2003). Developing parsimonious retailer equity indexes using partial least squares analysis: A method and applications. Journal of Retailing, 79(3), 161-170. http://dx.doi.org/10.1016/S0022-4359(03)00036-8

Atiligan, E., Aksoy, S., \& Akinci, S. (2005). Determinants of the brand equity: A verification approach in the beverage industry in Turkey. Marketing Intelligence and Planning, 23(3), 237-248. http://dx.doi.org/10.1108/02634500510597283

Baker, D. J., Blumberg, R., \& Freeman, R. (2002). Using Functional assessment and systems-level assessments to build effective behavioural support plans. New York: NADD.

Bloemer, J., \& Odekerken-Shroder, G. (2002). Stores satisfaction and store loyalty explained by customer and store related factors. Journal of Consumer Satisfaction, Dissatisfaction and Complaining Behaviour, 15, 68-80.

Carpenter, G. S., \& Tybout, A. M. (1998). Meeting the challenge of post modern consumer. Mastering Market Series. Financial Times, 2-3.

Chaudhuri, A., \& Holbrook, M. B. (2001). The chain of effects from brand trust and brand affect to brand performance: The Role of Brand Loyalty. Journal of Marketing, 65, 81-93. http://dx.doi.org/10.1509/jmkg.65.2.81.18255

Chen, C. (2001). Using free association to examine the relationship between the characteristics of brand associations and brand equity. The Journal of Product and Brand Management, 10(6/7), 43-45.

Chieng, F. Y., \& Goi, C. (2011). Customer based brand equity: A literature review. Retrieved from http://www.researcherdworld.com

Dick, A., \& Basu, K. (1994). Customer Loyalty towards an integrated framework. Journal of the Academy of Marketing Science, 22(2), 99-113. http://dx.doi.org/10.1177/0092070394222001

Erenkol, H. A. D., \& Duygun, A. (2010). Customers perceived brand equity and research on the customers of Bellona which is a Turkish Furniture brand. The Journal of American Academy of Business, 16(1), 93-110.

Evans, C., Storer, C., \& Johnson, A. W. (2011). Rural farming community climate change Acceptance: Impact of science and government credibility. International Journal of Sociology of Agriculture and Food, 18(3), 217-235. 
Fiore, A. M., \& Damhorst, M. L. (1992). Intrinsic cues as predictors of perceived quality of apparel. Journal of Consumer satisfaction, Dissatisfaction and Complaining Behaviour, 5, 168-178.

Grewal, D., Baker, J., Levy, M., \& Voss, B. G. (2003). The effects of wait expectations and store atmosphere evaluations on patronage intentions in service-intensive retail stores. Journal of Retailing, 79(4), 259-268. http://dx.doi.org/10.1016/j.jretai.2003.09.006

Gustafson, A., \& Johnson, M. D. (2002). Measuring and Managing the satisfaction-loyalty performance links at Volvo. Journal of Targeting, Measurement and Analysis for Marketing, 10(3), 249-258. http://dx.doi.org/10.1057/palgrave.jt.5740050

Johnson, M. D., Herrmann, A., \& Gustafson, A. (2002). Comparing customer satisfaction across industries and $\begin{array}{lllll}\text { countries. Journal of } & \text { Economic } & \text { Psychology, } & \text { 23(6), }\end{array}$ http://dx.doi.org/10.1016/S0167-4870(02)00137-X

Jones, J. T., Pelham, B. U. L., Mirenberg, M., \& Hetts, J. J. (2002). Name letter preferences are not merely mere exposure: Implicit egotism as self regulation. Journal of Experimental Social Psychology, 38, 170-177. $\mathrm{http}: / / \mathrm{dx}$.doi.org/10.1006/jesp.2001.1497

Kapferer, J. N. (1997). Strategic Brand Management. London: Kogan Page.

Keller, K. L. (1998). Strategic brand Management: Building Measuring and Managing Brand equity. Upper saddle River, NJ: Prentice Hall.

Keller, K. L. (2003). Strategic Brand Management. Upper saddle River, NJ: Prentice-Hall.

Keller, M. L. (1993). Conceptualizing, measuring, and managing customer-based brand equity. Journal of Marketing, 57(1), 1-22. http://dx.doi.org/10.2307/1252054

Kim, H. B., \& Kim, W. G. (2004). The effect of consumer-based equity on firmly financial performance. Journal of Consumer Marketing, 20(4), 335-351. http://dx.doi.org/10.1108/07363760310483694

Kramer, R. M. (1999). Trust and distrust in organizations: Emerging perspectives, enduring questions. Annual Review of Psychology, 50, 569-598. http://dx.doi.org/10.1146/annurev.psych.50.1.569

Krishnan, H. S. (1996). Characteristics of memory associations: A consumer-based brand equity perspective. International Journal of Research Marketing, 13(4), 389-405. http://dx.doi.org/10.1016/S0167-8116(96)00021-3

Mutsikiwa, M., \& Marumbwa, J. (2013). The impact of aesthetics package design Elements on Consumer Purchase designs: A case of locally Produced Dairy products in Southern Zimbabwe. Journal of Business and Management, 8(5), 64-71.

Nunnally, J. C. (1978). Psychometric theory (2nd ed.). New York: McGraw-Hill.

Oliver, R. L. (1999). Whence consumer loyalty? Journal of Marketing, 63(special issue), 33-44. http://dx.doi.org/10.2307/1252099

Pappu, R., Quester, P. G., \& Cooksey, R. M. (2005). Consumer based brand equity: improving the measurement empirical evidence. Journal of Product and Brand Management, 14(3), 143-154. http://dx.doi.org/10.1108/10610420510601012

Porter, S., \& Claycomb, C. (1997). The influence of brand recognition on retail store image. Journal of Product and Brand Management, 6(6), 373-387. http://dx.doi.org/10.1108/10610429710190414

Salkind, M. J. (2008). Encyclopaedia of Educational Psychology. London: Sage publications.

Steenkamp, J. B. E. M. (1997). The Importance of intrinsic and extrinsic cues to expected and experienced quality: An empirical application for beef. Food Quality and Preference, 11(200), 229-238.

Thompson, R. A. (1998). Early socio personality development. In N. Eisenberg (Ed.), Handbook of Child Psychology and personality development (5th ed., pp. 25-104). New York: Uliley.

Washburn, J. H., \& Plank, R. E. (2002). Measuring brand equity: An evaluation of a consumer-based brand equity scale. Journal of Marketing Theory and Practice, 10(1), 46-62.

Yoo, B., Donthu, N., \& Lee, S. C. (2000). An examination of selected marketing mix elements and brand equity. Journal of the Academy of Marketing Science, 28(2), 195-211. http://dx.doi.org/10.1177/0092070300282002

Zeithaml, V. A. (1988). Consumer perceptions of price, quality, and value: A means-end model and synthesis of 
evidence. Journal of Marketing, 52(3), 2-22.

\section{Copyrights}

Copyright for this article is retained by the author(s), with first publication rights granted to the journal.

This is an open-access article distributed under the terms and conditions of the Creative Commons Attribution license (http://creativecommons.org/licenses/by/3.0/). 